\title{
Something of a song for Stephen Gray
}

Your stance and the ferocity of your frown shows that you know, that you've always known, exactly who Stephen Gray should truly be.

I envy you this surety of self but, of course, that's only the Italian you. The 'accident of your birth', here at home, still ripples on, still doubts itself sometimes, still stumbles, yet shares that same forthrightness. Between local talk, Adamastor, and Shelley, I've found you and have made you my own. Though I hate your love of popular politics and complacent academic air, I look at you there, in that photo Giovanni took, and I see my own truth, our truth. 